\title{
The Effect of Allium cepa Extract on Lung Oxidant, Antioxidant, and Immunological Biomarkers in Ovalbumin-Sensitized Rats
}

\author{
N. Marefati ${ }^{a, b} \quad$ N. Eftekhar ${ }^{b} \quad$ M. Kaveh ${ }^{b} \quad$ J.Boskabadi ${ }^{a}$ b $\quad$ F. Beheshti ${ }^{b}$ \\ M.H. Boskabadya, b \\ a Neurogenic Inflammation Research Center, Mashhad University of Medical Sciences, Mashhad, Iran; \\ ${ }^{b}$ Department of Physiology, School of Medicine, Mashhad University of Medical Sciences, Mashhad, Iran
}

\section{Significance of the Study}

- In this study, the effects of Allium cepa extract on oxidant, antioxidant, and immunological marker levels were evaluated in bronchoalveolar lavage fluid of sensitized rats. The A. cepa extract showed antioxidant and immunomodulatory effects in bronchoalveolar lavage fluid of sensitized rats, which could indicate the therapeutic potential of this extract in asthma.

\section{Keywords}

Asthma $\cdot$ Allium cepa $\cdot$ Antioxidants $\cdot$ Immunomodulation

\begin{abstract}
Objectives: To evaluate the effects of Allium cepa (A. cepa) on levels of oxidants, antioxidants, and immunological markers in bronchoalveolar lavage fluids (BALF) of sensitized rats. Materials and Methods: Oxidant/antioxidant markers and cytokines in BALF of control rats treated with saline (group C), ovalbumin-sensitized rats (group S), rats treated with 1.25 $\mu \mathrm{g} / \mathrm{mL}$ dexamethasone and 3 doses of $A$. cepa extract $(35,70$, and $140 \mathrm{mg} / \mathrm{kg}$ body weight [BW]/day) $(\mathrm{S}+\mathrm{AC})$ were investigated. Comparison of the results between groups was performed using analysis of variance with the Tukey-Kramer post hoc test. Results: The oxidant markers nitrogen dioxide $\left(\mathrm{NO}_{2}\right)$, nitrate $\left(\mathrm{NO}_{3}{ }^{-}\right)$, and malondialdehyde (MDA), and immunological markers interleukin (IL)-4 and immunoglobulin $\mathrm{E}(\mathrm{IgE})$ were significantly higher, but the antioxidant markers
\end{abstract}

\begin{tabular}{ll}
\hline KARGER & $\begin{array}{l}\text { (C) } 2018 \text { The Author(s) } \\
\text { Published by S. Karger AG, Basel }\end{array}$ \\
E-Mail karger@karger.com & $\begin{array}{l}\text { This is an Open Access article licensed under the Creative Commons } \\
\text { Attribution-NonCommercial-4.0 International License (CC BY-NC) } \\
\text { (http://www.karger.com/Services/OpenAccessicense), applicable to } \\
\text { the online version of the article only. Usage and distribution for } \\
\text { commercial purposes requires written permission. }\end{array}$
\end{tabular}

superoxide dismutase (SOD), catalase (CAT), thiol, and interferon (IFN) $-\gamma$, and the IFN- $\gamma /$ IL- 4 ratio were lower in sensitized rats compared to control rats ( $p<0.001$ to $p<0.01$ ). Compared to group $S$, the levels of the following markers were significantly lower: $\mathrm{NO}_{2}, \mathrm{NO}_{3}{ }^{-}$, and IgE in groups treated with the A. cepa extract, MDA and IL-4 levels in groups treated with 70 and $140 \mathrm{mg} / \mathrm{kg} \mathrm{BW/day} \mathrm{of} \mathrm{the} A$. cepa extract, and all these markers as well as IFN- $\gamma$ in rats treated with dexamethasone $(p<0.001$ to $p<0.05)$. However, there were significantly higher levels of SOD and CAT and an increased IFN- $\gamma$ / IL-4 ratio (groups treated with 70 and $140 \mathrm{mg} / \mathrm{kg}$ BW/day of the $A$. cepa extract), and levels of thiol and IFN- $\gamma$ (group treated with $140 \mathrm{mg} / \mathrm{kg}$ BW/day of the $A$. cepa extract) as well as SOD, CAT, and thiol (dexamethasone-treated group) versus group $S(p<0.00$ to $p<0.05)$. Conclusion: A. cepa showed antioxidant and immunomodulatory properties in sensitized rats.

(c) 2018 The Author(s)

Published by S. Karger AG, Basel
Mohammad Hossein Boskabady

Neurogenic Inflammation Research Center

Mashhad University of Medical Sciences

Mashhad (Iran)

E-Mail boskabadymh@mums.ac.ir or boskabadymh@gmail.com 


\section{Introduction}

Bronchial asthma is the most common chronic disease worldwide [1] which involves the immune system [2]. Many cells are involved in its pathogenesis, such as dendritic cells (Th2), lymphocytes, eosinophils, mast cells, neutrophils, macrophages, epithelial cells, fibroblasts, and smooth muscle cells [2]. These cells release inflammatory mediators such as histamine, prostaglandin $\mathrm{D}_{2}$, leukotrienes, cytokines, chemokines, oxidative markers, and nitric oxide [2, 3]. In an immune-mediated disorder like asthma, Th2 cytokines such as IL-4, IL-5, and IL-13 initiate allergic responses by increasing the infiltration of eosinophils and enhancement of the production of IgE and Th1 cytokines (interferon [IFN]- $\gamma$ ), which inhibit Th2 responses [3]. Inflammatory cells such as macrophages and eosinophils generate reactive oxygen species, and hence oxidative stress is increased in patients with asthma [4]. Increased oxidative stress is associated with disease severity and may enhance the inflammatory response [4]. The main therapeutic strategies used for treatment of asthma focus on reducing airway inflammation, but there is no definite cure for reducing the airway remodeling observed in this disease [1].

Allium cepa belongs to the Liliaceae family, grows around the world, and has been used as a food ingredient [1]. A. cepa contains pharmacologically active constituents, including flavonoids (quercetin), organosulfur compounds (propyl thiosulfinate), and phenol components, which possess anti-allergic [5], anti-inflammatory, and antioxidant activities [6]. Graefe et al. [7] showed that the bioavailability of the active quercetin metabolites (glucuronides) in human blood is about 5 times higher than that of quercetin and only about $66 \%$ of that of the corresponding plant extract. Peak concentrations of quercetin were observed $7.0 \pm 2.9 \mathrm{~h}$ after ingestion, and its elimination half-life was about $11 \mathrm{~h}$. Also, the plant matrix influences both the rate and extent of absorption. This plant acts as a booster of the immune system [8], and its effect on cytokines reflects its immunomodulatory property [9]. Anti-asthmatic properties of the extract of $A$. серa and its constituent quercetin on cytokines, inflammatory cells, and smooth muscle contraction were shown in a murine model of asthma [10]. Allergic contact dermatitis or irritation and anemia were reported for A. cepa oil or its aqueous extract [11]. However, no toxic effect was observed in mice following the oral administration of $1,000 \mathrm{mg} / \mathrm{kg}$ body weight (BW)/day of A. cepa extract [10]. Moreover, no mutagenicity or oxidative DNA damage was induced by propyl propane thiosulfinate derived from organosulfur compounds isolated from A. серa $[12,13]$.

Hence, with regard to alterations in the oxidant/antioxidant balance and cytokine changes in asthma and due to its antioxidant and immunomodulatory effects, the objective of the present study was to evaluate the effects of $A$. cepa extract on bronchoalveolar lavage fluid (BALF) levels of oxidant and antioxidant markers, IgE, and cytokines in sensitized rats.

\section{Materials and Methods}

\section{Plant and Extract}

A. cepa (onion) was collected and peeled, and its juice was obtained using a fruit juice producer (Pars Khazar, Iran). The extract was concentrated by evaporation using a rotary evaporator at $60-70{ }^{\circ} \mathrm{C}$ and then dehydrated in an oven.

\section{Experimental Groups and Ovalbumin Sensitization}

In this study, 36 male Wistar rats weighing 200-250 g were studied. The rats were kept in the animal house under standard conditions (at $22 \pm 2{ }^{\circ} \mathrm{C}$ at a 12 -h light/dark cycle) with clean filtered air (Maximiser, Thorens Caging System Inc., Hazleton, PA, USA) at the School of Medicine, Mashhad University of Medical Sciences, Mashhad, Iran. Three rats were kept in each cage, and they had free access to water and food.

The rats were sensitized intraperitoneally once a day for 3 days with $1 \mathrm{mg} / \mathrm{kg}$ ovalbumin (OVA) dissolved in $0.9 \%$ saline $+100 \mathrm{mg}$ aluminum hydroxide as adjuvant. Thirty rats were then exposed to $1 \%$ OVA aerosol produced by a nebulizer (DeVilbiss Health Care Ltd., Feltham, UK) for $20 \mathrm{~min} /$ day with an air flow of $8 \mathrm{~L} / \mathrm{min}$ on days $6,9,12,15,18$, and 21. Exposure of rats to OVA was done in a $0.8-\mathrm{m}^{3}$ chamber [14].

The 36 rats were divided into 6 groups ( $n=6$ in each group) as follows: (a) control rats received intraperitoneal and inhaled saline (group C); (b) sensitized but untreated rats (group S); (c) sensitized rats treated with $1.25 \mu \mathrm{g} / \mathrm{mL}$ dexamethasone added to the drinking water during the sensitization period (on days 1-21) (group S + $\mathrm{D})$; and $(\mathrm{d}-\mathrm{f})$ sensitized groups treated with $A$. cepa extract at 3 doses $(0.175,0.35$, or $0.7 \mathrm{mg} / \mathrm{mL}$, respectively) added to the drinking water during the sensitization period (days 1-21), which corresponded to 35,70 , and $140 \mathrm{mg} / \mathrm{kg}$ BW/day, respectively. The doses were chosen based on the study of Oliveira et al. [10]. Each rat drank an average of $40 \mathrm{~mL}$ water/day. Experiments on rats were done according to the national laws and the Guidelines for the Use and Care of Laboratory Animals (National Institutes of Health, USA). The study was approved by the Ethics Committee of the Mashhad University of Medical Sciences.

\section{BALF Preparation}

All rats were sacrificed on day 22, their chests opened, and trachea and lungs were separated. The left lung was lavaged 5 times with $1 \mathrm{~mL}$ saline (a total of $5 \mathrm{~mL}$ ). The BALF was centrifuged at $2,500 \mathrm{~g}$ at $4^{\circ} \mathrm{C}$ for $10 \mathrm{~min}$. Supernatants were collected and stored at $-80^{\circ} \mathrm{C}$ until analysis. 


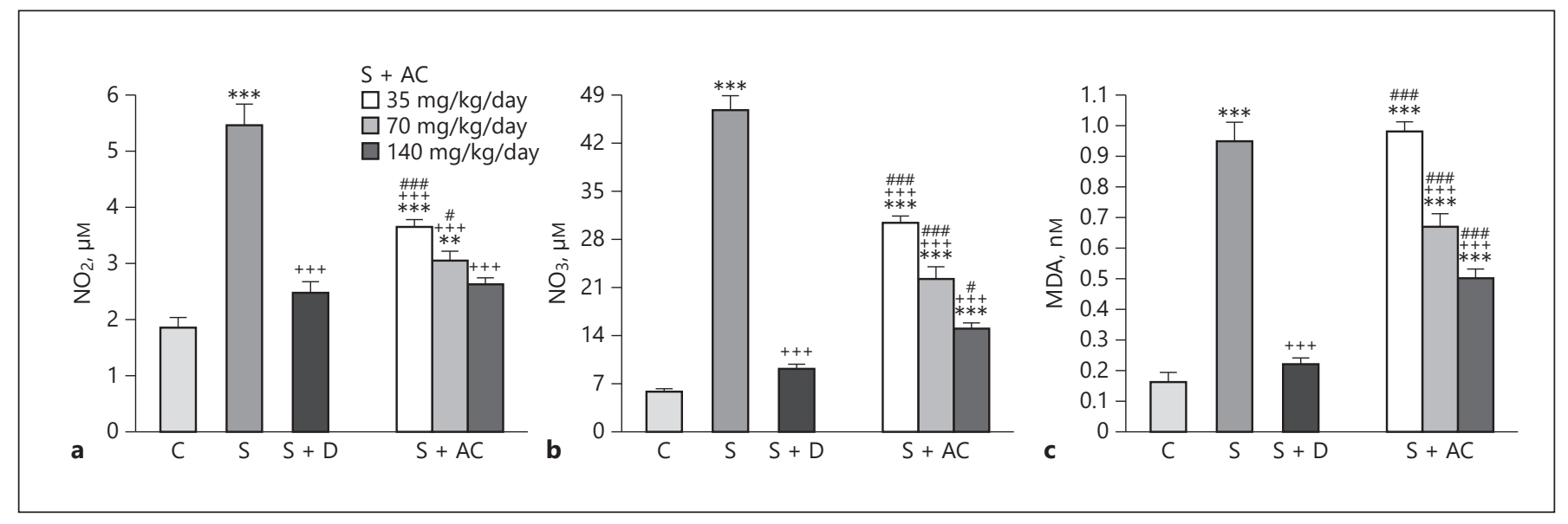

Fig. 1. Levels of $\mathrm{NO}_{2}(\mathbf{a}), \mathrm{NO}_{3}(\mathbf{b})$, and malondialdehyde (MDA) (c) in the bronchoalveolar lavage fluid of control rats $(\mathrm{C})$, sensitized rats $(\mathrm{S})$, sensitized rats treated with dexamethasone $(\mathrm{S}+\mathrm{D})$ and Allium cepa $(35,70$, and 140 $\mathrm{mg} / \mathrm{kg} \mathrm{BW} /$ day) $(\mathrm{S}+\mathrm{AC}) .{ }^{* *} p<0.01,{ }^{* * *} p<0.001$, vs. group $\mathrm{C} ;{ }^{+++} p<0.001$ vs. group $\mathrm{S} ;{ }^{\#} p<0.05,{ }^{\# \# \#} p<0.001$, vs. group $\mathrm{S}+\mathrm{D}$.

Measurement of Oxidant and Antioxidant Levels in BALF

Total stable oxidation products of $\mathrm{NO}$ metabolism $\left(\mathrm{NO}_{2}^{-}-\right.$ $\mathrm{NO}_{3}{ }^{-}$) in BALF supernatant were evaluated using the Griess reagent. The Griess reagent contains sulfanilamide (SULF; Sigma, USA) and N-(1-naphthyl)ethylenediamine dihydrochloride (NEDD). The frozen BALF samples were thawed at $25^{\circ} \mathrm{C}$ and deproteinized using zinc sulfate solution (Sigma). The liquefied BALF was then centrifuged at $12,000 \mathrm{~g}$ for $10 \mathrm{~min}$. Next, $300 \mu \mathrm{L}$ of the clear supernatant were mixed with Griess reagent containing $300 \mu \mathrm{L} \operatorname{SULF}(2 \% \mathrm{w} / \mathrm{v})$ in $5 \% \mathrm{HCl}$ and $300 \mu \mathrm{L} \mathrm{NEDD}(0.1 \% \mathrm{w} / \mathrm{v}$; Sigma) in water in a test tube. To reduce nitrate to nitrite, $300 \mu \mathrm{L}$ of saturated vanadium trichloride solution (Sigma) in $1 \mathrm{M} \mathrm{HCl}$ were added and incubated for $2 \mathrm{~h}$ at $30^{\circ} \mathrm{C}$ in the dark. Then, the absorbance of samples was assessed at $540 \mathrm{~nm}$ against a blank containing the same concentrations of ingredients but no biological sample. Linear regression was used to determine NO concentrations using a standard curve plotted for $\mathrm{NaNO}_{2}$. The final results are expressed as micromoles [14].

Levels of malondialdehyde (MDA), an index of lipid peroxidation, were measured. MDA reacts with thiobarbituric acid (TBA) as a TBA-reactive substance to produce a red-colored complex with maximum absorbance at $535 \mathrm{~nm}$. For MDA measurement, $2 \mathrm{~mL}$ of TBA/trichloroacetic acid/HCl was added to $1 \mathrm{~mL}$ of BALF supernatant, and the mixture was heated in a water bath for 40 $\mathrm{min}$. Then, the mixture was centrifuged at $1,000 \mathrm{~g}$ for $10 \mathrm{~min}$, and absorbance was measured at $535 \mathrm{~nm}$ [14].

Total thiol concentration was measured using 5,5'-dithiobis2-nitrobenzoic acid (DTNB) reagent which reacts with thiol moieties to produce a yellow-colored complex with maximum absorbance at $412 \mathrm{~nm}$. Briefly, $1 \mathrm{~mL}$ Tris-ethylenediaminetetraacetic acid (Tris-EDTA) buffer ( $\mathrm{pH}$ 8.6) was added to $50 \mu \mathrm{L}$ serum supernatant in 1-mL cuvettes, and sample absorbance was read at $412 \mathrm{~nm}$ against Tris-EDTA buffer alone $\left(\mathrm{A}_{1}\right)$. Then, $20 \mu \mathrm{L}$ DTNB reagent (10 $\mathrm{mM}$ in methanol) was added to the mixture, and absorbance was read again after $15 \mathrm{~min}$ at room temperature (RT) $\left(\mathrm{A}_{2}\right)$. The absorbance of the DTNB reagent alone was also read as a blank (B). Total thiol concentration (mM) was calculated using the following equation [14]:

Total thiol concentration $(\mathrm{mM})=\left(\mathrm{A}_{2}-\mathrm{A}_{1}-\mathrm{B}\right) \times 1.07 / 0.05 \times 13.6$.

Superoxide dismutase (SOD) was assessed using a colorimetric assay involving the production of superoxide by pyrogallol autooxidation and the prevention of superoxide-dependent diminution of the tetrazolium dye (3-[4,5-dimethylthiazol-2-yl]-2,5diphenyltetrazolium bromide [MTT]) to formazan by SOD [14]. One unit of SOD activity was defined as the quantity of enzyme required for $50 \%$ prevention in the MTT reduction rate.

Catalase (CAT) activity was assessed based on the rate constant, $\mathrm{k}$, (dimension: $\mathrm{s}^{-1}, \mathrm{k}$ ) of hydrogen peroxide decomposition. The reduction in absorbance at $240 \mathrm{~nm}$ per minute and the rate constant of the enzyme were determined. Activities were defined as $\mathrm{k}$ (rate constant) per liter [14].

\section{Measurement of Cytokines and IgE in BALF}

Levels of IL-4, IFN- $\gamma$, and IgE were measured by enzymelinked immunosorbent assay (Abcam, Cambridge, UK). The tests were done according to the manufacturer's instructions [15]. Briefly, $100 \mu \mathrm{L}$ of detection antibody was added to all wells (except for the blank), mixed, and incubated for 16-24 h at RT. Plates were washed 3 times, and standards or supernatants added to the respective wells in duplicate. After incubation, the plates were washed again and incubated with $200 \mu \mathrm{L}$ of the conjugate for 60 min at RT. Plates were then washed 3 times, and $200 \mu \mathrm{L}$ of substrate were added and incubated for $15 \mathrm{~min}$ at RT in the dark. The reaction was ended by the addition of $50 \mu \mathrm{L}$ of stop solution, and the color produced was measured using an automated microplate spectrophotometer. Total cytokine concentrations were determined as picograms per milligram of gingival tissue. Results were calculated using the standard curves plotted for each assay. The assays were carried out in a blind fashion in duplicate [16]. The interassay coefficients of variation for IFN- $\gamma$, IL-4, and IgE were $<12,5.9$, and $<10 \%$, respectively. 


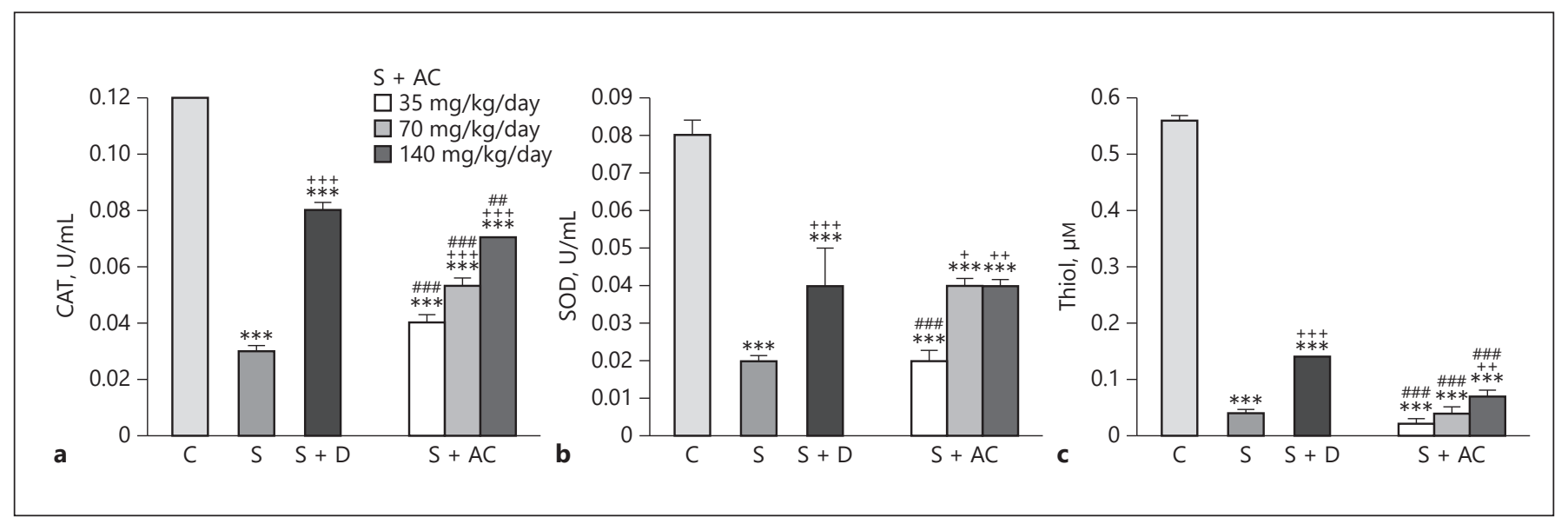

Fig. 2. Levels of catalase (CAT) (a), superoxide dismutase (SOD) (b), and thiol (c) in the bronchoalveolar lavage fluid of control rats (C), sensitized rats (S), sensitized rats treated with dexamethasone (S + D) and Allium cepa $\left(35,70\right.$, and $140 \mathrm{mg} / \mathrm{kg} \mathrm{BW} /$ day) $(\mathrm{S}+\mathrm{AC}) .{ }^{* * *} p<0.001$ vs. group $\mathrm{C} ;{ }^{+} p<0.05,{ }^{++} p<0.01,{ }^{+++} p<0.001$, vs. group $\mathrm{S} ;{ }^{\# \#} p<0.01,{ }^{\# \# \#} p<0.001$, vs. group S + D.

Statistical Analysis

Analysis of variance (ANOVA) was used for comparisons among groups with the Tukey-Kramer post hoc test. Significance was considered as $p<0.05$. InStat software (GraphPad Software, Inc., La Jolla, CA, USA) was used for statistical analyses. Data are presented as means \pm SEM.

\section{Results}

\section{Effect of A. cepa on Oxidant and Antioxidant}

Markers in BALF

The volume of water used by animals did not significantly vary among the different groups. $\mathrm{NO}_{2}, \mathrm{NO}^{-}$, and MDA levels were higher in the BALF in group $\mathrm{S}$ than in the control group ( $p<0.001$ for all cases). $\mathrm{NO}_{2}$ and $\mathrm{NO}_{3}{ }^{-}$ levels were significantly reduced in rats treated with dexamethasone and one of the 3 doses of A. cepa, and MDA level was lower in rats treated with dexamethasone plus 70 and $140 \mathrm{mg} / \mathrm{kg} \mathrm{BW/day} \mathrm{A.} \mathrm{cepa} \mathrm{compared} \mathrm{to} \mathrm{group} \mathrm{S}$ $(p<0.001$ for all cases; Fig. 1). The effects of the A. cepa extract on MDA and $\mathrm{NO}_{3}{ }^{-}$levels and the effect of 35 and $70 \mathrm{mg} / \mathrm{kg}$ BW/day A. cepa on $\mathrm{NO}_{2}$ were significantly lower compared to that of dexamethasone treatment $(p<$ 0.001 to $p<0.05$; Fig. 1 ).

The effects of $140 \mathrm{mg} / \mathrm{kg} \mathrm{BW/day} \mathrm{A.} \mathrm{cepa} \mathrm{on} \mathrm{all} \mathrm{oxi-}$ dant biomarkers were significantly more pronounced than that of $35 \mathrm{mg} / \mathrm{kg} \mathrm{BW/day} \mathrm{A.} \mathrm{cepa} \mathrm{(} p<0.001$ to $p<$ 0.05 ; Table 1). In addition, the effect of the $70 \mathrm{mg} / \mathrm{kg} \mathrm{BW/}$ day $A$. cepa dose on $\mathrm{MDA}$ and $\mathrm{NO}_{3}{ }^{-}$was significantly more marked than its lowest dose but less marked than
Table 1. Comparison of oxidant, antioxidant, cytokine, and $\operatorname{IgE}$ levels

\begin{tabular}{lrcc}
\hline Parameters & S + AC 35 & S + AC 70 & S + AC 140 \\
\hline MDA, nM & $0.98 \pm 0.02$ & $0.66 \pm 0.04^{* * *}$ & $0.49 \pm 0.03^{* * *,+}$ \\
$\mathrm{NO}_{2}, \mu \mathrm{M}$ & $3.66 \pm 0.11$ & $3.05 \pm 0.15$ & $2.62 \pm 0.11^{*}$ \\
$\mathrm{NO}_{3}, \mu \mathrm{M}$ & $30.46 \pm 0.89$ & $22.21 \pm 1.85^{* *}$ & $15.08 \pm 0.81^{* * *,+}$ \\
$\mathrm{CAT}, \mathrm{U} / \mathrm{mL}$ & $0.03 \pm 0.00$ & $0.05 \pm 0.00^{* * *}$ & $0.06 \pm 0.00^{* * *,+}$ \\
$\mathrm{SOD}, \mathrm{U} / \mathrm{mL}$ & $0.01 \pm 0.00$ & $0.03 \pm 0.00^{* * *}$ & $0.04 \pm 0.00^{* *}$ \\
$\mathrm{Thiol}, \mu \mathrm{M}$ & $0.02 \pm 0.00$ & $0.04 \pm 0.00$ & $0.06 \pm 0.00^{* * *,+}$ \\
$\mathrm{IL}-4, \mathrm{pg} / \mathrm{mL}$ & $6.85 \pm 0.12$ & $4.47 \pm 0.02^{* * *}$ & $3.75 \pm 0.06^{* * *,++}$ \\
$\mathrm{INF}-\gamma, \mathrm{pg} / \mathrm{mL}$ & $2.48 \pm 0.03$ & $2.80 \pm 0.01^{* * *}$ & $3.06 \pm 0.02^{* * *,++}$ \\
$\mathrm{INF}-\gamma / \mathrm{IL}-4$ & $0.36 \pm 0.00$ & $0.62 \pm 0.00^{* * *}$ & $0.81 \pm 0.01^{* * *,++}$ \\
IgE, ng/mL & $32.64 \pm 1.42$ & $24.19 \pm 0.65^{* *}$ & $16.67 \pm 0.55^{* * *,++}$ \\
\hline
\end{tabular}

Means \pm SEM. S + AC 35/70/140, sensitized animals treated with $35 / 70 / 140 \mathrm{mg} / \mathrm{kg}$ BW/day Allium cepa extract. See text for further abbreviations. ${ }^{*} p<0.05,{ }^{* *} p<0.01,{ }^{* * *} p<0.001$, vs. $\mathrm{S}+$ AC $35 ;{ }^{+} p<0.05,{ }^{++} p<0.01,{ }^{+++} p<0.001$, vs. $S+$ AC 70 (ANOVA).

the highest dose $(p<0.001$ to $p<0.05$; Table 1$)$. Levels of SOD, thiol, and CAT were significantly decreased in sensitized rats compared to the control group ( $p \leq 0.001$ for all cases; Fig. 2). Levels of CAT and SOD in rats treated with dexamethasone and 70 and $140 \mathrm{mg} / \mathrm{kg} \mathrm{BW/day} A$. сер $a$ and the level of thiol in the groups treated with dexamethasone and $140 \mathrm{mg} / \mathrm{kg} \mathrm{BW/day} \mathrm{A.} \mathrm{cepa} \mathrm{were} \mathrm{signifi-}$ cantly increased compared to the sensitized group $(p<$ 0.001 to $p<0.05$; Fig. 2 ). 
Fig. 3. Levels of interleukin (IL)-4 (a) and interferon (IFN) $-\gamma(\mathbf{b})$ in the bronchoalveolar lavage fluid of control rats (C), sensitized rats $(S)$, sensitized rats treated with dexamethasone $(\mathrm{S}+\mathrm{D})$ and Allium cepa $(35,70$, or $140 \mathrm{mg} / \mathrm{kg} \mathrm{BW/day)}(\mathrm{S}+\mathrm{AC})$. ** $p<0.01$, *** $p<0.001$, vs. group C; ${ }^{++} p<0.01,{ }^{+++} p<0.001$, vs. group $S ;{ }^{\# \#} p<$ $0.01,{ }^{\# \# \#} p<0.001$, vs. group $\mathrm{S}+\mathrm{D}$.
Fig. 4. The interferon (IFN)- $\gamma$ /interleukin (IL)-4 ratio (a) and IgE levels (b) in the bronchoalveolar lavage fluid of control rats (C), sensitized rats $(S)$, sensitized rats treated with dexamethasone (S+D) and Allium cepa $(35,70$, and $140 \mathrm{mg} / \mathrm{kg} /$ day $)$ $(\mathrm{S}+\mathrm{AC}) .{ }^{*} p<0.05,{ }^{* *} p<0.01,{ }^{* * *} p<$ 0.001 , vs. group $\mathrm{C}$; ${ }^{++} p<0.01,{ }^{+++} p<$ 0.001 , vs. group $S ;{ }^{\#} p<0.05,{ }^{\# \#} p<0.001$, vs. group $\mathrm{S}+\mathrm{D}$.
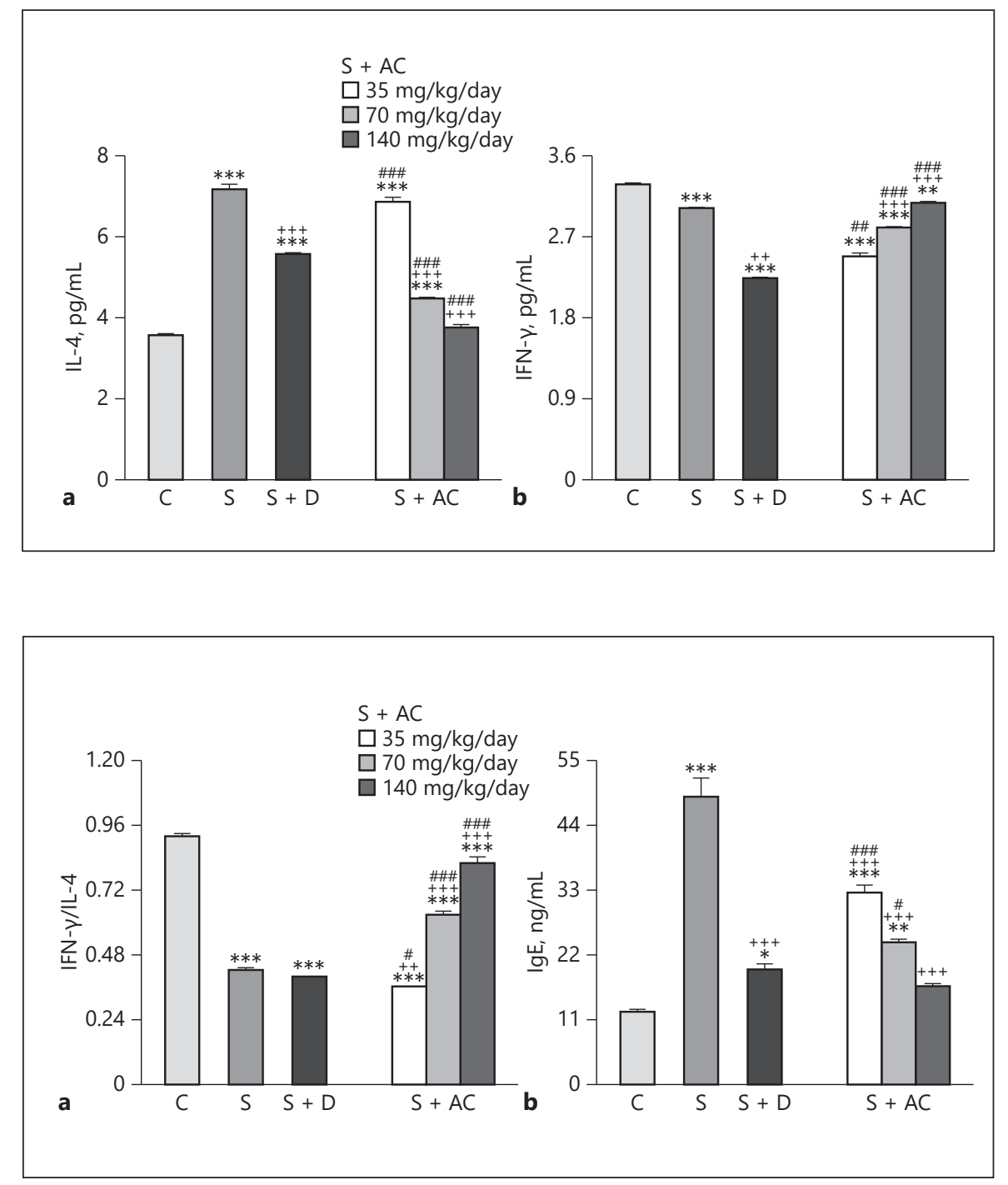

The effects of all 3 doses of $A$. cepa extract on CAT and thiol and the effect of the 35 and $70 \mathrm{mg} / \mathrm{kg}$ BW/day doses on SOD were significantly lower than those of dexamethasone alone ( $p<0.001$ to $p<0.05$; Fig. 1). The effects of the $140 \mathrm{mg} / \mathrm{kg}$ BW/day dose on all antioxidant biomarkers and the effect of its $70 \mathrm{mg} / \mathrm{kg}$ BW/day dose on CAT and SOD were significantly higher than those of the 35 $\mathrm{mg} / \mathrm{kg} \mathrm{BW} /$ day dose $(p<0.001$ to $p<0.05$; Table 1$)$. The effects of the $140 \mathrm{mg} / \mathrm{kg} \mathrm{BW/day} \mathrm{dose} \mathrm{on} \mathrm{CAT} \mathrm{and} \mathrm{thiol}$ were also significantly higher than the $70 \mathrm{mg} / \mathrm{kg}$ BW/day dose $(p<0.001$ to $p<0.05$; Table 1$)$.

\section{Effect of A. cepa on Immunological Markers in BALF}

Levels of IL- 4 and IgE were higher, but levels of IFN- $\gamma$ and the IFN- $\gamma / \mathrm{IL}-4$ ratio were lower in sensitized than control rats ( $p<0.001$ for all cases; Fig. 3, 4). Levels of IgE in sensitized groups treated with all A. cepa doses, and levels of IL-4 in groups treated with the 70 and $140 \mathrm{mg} /$ $\mathrm{kg} \mathrm{BW/day} \mathrm{doses} \mathrm{were} \mathrm{significantly} \mathrm{lower} \mathrm{than} \mathrm{in} \mathrm{un-}$ treated rats $(p<0.001$ for both cases; Fig. 3$)$. In addition, the level of IFN- $\gamma$ and the IFN- $\gamma /$ IL- 4 ratio were higher in groups treated with 70 and $140 \mathrm{mg} / \mathrm{kg}$ BW/day doses of the extract ( $p<0.001$ for both cases; Fig. 4). However, dexamethasone treatment caused significant reductions in IgE, IL-4, and IFN- $\gamma$ levels but did not affect the IFN- $\gamma$ / IL- 4 ratio $(p<0.05$ for IFN- $\gamma$ and $p<0.001$ for IgE and IL-4; Fig. 3, 4).

The effects of the $35 \mathrm{mg} / \mathrm{kg} \mathrm{BW} /$ day $A$. cepa dose on IL- 4 and the IFN- $\gamma / \mathrm{IL}-4$ ratio as well as the effects of the 35 and $70 \mathrm{mg} / \mathrm{kg}$ BW/day A. cepa doses on $\operatorname{IgE}$ were 
significantly lower than those of dexamethasone $(p<0.01$ for the IFN- $\gamma / \mathrm{IL}-4$ ratio and $p<0.001$ for the other cases; Fig. 3, 4). However, the effect of the 70 and $140 \mathrm{mg} / \mathrm{kg}$ BW/day A. cepa doses on IL-4 and IFN- $\gamma$ levels as well as the IFN- $\gamma / \mathrm{IL}-4$ ratio and the effect of the $140 \mathrm{mg} / \mathrm{kg} \mathrm{BW/}$ day $A$. cepa dose on IgE level were significantly more marked than the effect of dexamethasone $(p<0.001$ for all cases; Fig. 3, 4). The effects of the 70 and $140 \mathrm{mg} / \mathrm{kg}$ $\mathrm{BW} /$ day A. cepa doses on all immunological parameters were significantly more pronounced than the $35 \mathrm{mg} / \mathrm{kg}$ BW/day dose $(p<0.001$ to $p<0.01$; Table 1$)$. The effects of the $140 \mathrm{mg} / \mathrm{kg} \mathrm{BW/day} \mathrm{dose} \mathrm{on} \mathrm{immunological} \mathrm{param-}$ eters were also significantly higher than the $70 \mathrm{mg} / \mathrm{kg}$ BW/day dose $(p<0.001$ to $p<0.01$; Table 1$)$.

\section{Discussion}

In this study, the level of the oxidant markers $\mathrm{NO}_{2}$, $\mathrm{NO}_{3}{ }^{-}$, and MDA were lower but antioxidant markers CAT, SOD, and thiol were higher in the BALF of the sensitized rats than the control rats. Levels of IL- 4 were also higher but IFN- $\gamma$ and the IFN- $\gamma / \mathrm{IL}-4$ ratio were lower in the BALF of sensitized than control rats. Previous studies in sensitized rats using similar methods of sensitization to the method used in this study also showed changes in oxidant and antioxidant levels as well as changes in IL-4 and IFN- $\gamma$ levels, and the IFN- $\gamma / \mathrm{IL}-4$ ratio $[15,17,18]$, which support the findings of the present study.

Studies have reported the role of oxidative stress in asthmatic airway inflammation [19], reflected by increased levels of oxidants in a rat model of asthma and in asthmatic patients [20], and increased plasma levels of MDA in the BALF of asthmatic patients [21].

Marked antioxidant properties of red and yellow $A$. cepa skin have been shown to be due to the presence of flavonoids and organosulfur compounds [22], and the antioxidant effect of $A$. cepa was also documented in $A$. cepa-enriched bread [23]. The results of the present study suggest the potential therapeutic effect of $A$. cepa extract on asthma due to its antioxidant effect.

The A. cepa extract also reduced IgE and IL-4 levels but increased the IFN- $\gamma / \mathrm{IL}-4$ ratio in the BALF of sensitized rats, indicating that $A$. cepa has immunomodulatory effects.

The suppressive effects of the plant and its constituents, such as quercetin, on IL- 6 , TNF- $\alpha$, and IL- $1 \beta$, and expression of COX-2, iNOS, NF- $\kappa$ B, and MAPKs have been reported [24]. The inhibitory effect of quercetin on the production of IL-4, a Th2 cytokine, and its stimulatory effect

Effect of Allium cepa on Oxidative and

Immune Biomarkers in the Rat Lung on the production of IFN- $\gamma$, a Th1 cytokine [25], were also shown in asthmatic mice, which support the findings of the present study and indicate that the plant is able to contribute to the treatment of asthma by increasing the Th1/Th2 balance and decreasing the levels of IgE.

The effects of $A$. cepa on oxidant and antioxidant markers, cytokines, and IgE in sensitized mice were also supported by the study of Oliveira et al. [10]. In a murine model of Blomia tropicalis-induced asthma, Oliveira et al. [10] showed the suppressive effect of A. cepa L. extract and quercetin on inflammatory activities such as eosinophil infiltration in the lung, eosinophil peroxidase, the cytokines IL-4 and IL-5, as well as smooth muscle contraction. The effect of the extract on eosinophil infiltration and eosinophil peroxidase was greater than that of quercetin. The effect of the extract and quercetin on cytokines was similar, but the effect of quercetin on tracheal smooth muscles relaxation was greater than that of the extract. They studied the effect of $A$. cepa extract (100 and $1,000 \mathrm{mg} / \mathrm{kg} /$ day for 6 days) and quercetin in rats sensitized with B. tropicalis, but in the present study the A. cepa extract was tested on OVA-sensitized rats for 21 days. Various pharmacological effects, including antioxidant and anti-allergic effects, immune system stimulation, improved Th1/Th2 balance, and reduction of proinflammatory cytokine levels have been reported for onion-derived quercetin supporting its possible contribution to the therapeutic effects of $A$. cepa in bronchial asthma [26].

Dexamethasone decreased the levels of oxidant markers, and IgE and IL-4 levels, but improved antioxidant levels. However, dexamethasone did not increase IFN- $\gamma$ levels or the IFN- $\gamma / \mathrm{IL}-4$ ratio. The effects of the plant on the levels of oxidant and antioxidant markers $\mathrm{NO}_{3}{ }^{-}$, MDA, CAT, and thiol were less marked than those of dexamethasone. However, the effects of the extract on IL- 4 , IFN- $\gamma$, and the IFN- $\gamma /$ IL- 4 ratio were more marked, but the effect on IgE was comparable to that of dexamethasone. Therefore, A. cepa showed less oxidant and antioxidant activity than dexamethasone but demonstrated more specific immunomodulatory effects by reducing levels of the Th2 cytokine IL- 4 and increasing levels of the Th1 cytokine IFN- $\gamma$ and the IFN- $\gamma / \mathrm{IL}-4$ ratio resulting in enhanced Th1/Th2 bias. However, the effect of the plant extract on other cytokines such as IL-8 and tumor necrosis factor should be evaluated in further studies [27]. It should also be noted that different results may also be related to the type of species chosen. In fact, it was shown that components and activities of onion are different on the basis of cultivars [28]. 
The role of thiol, an early marker of oxidative stress in asthma, in the reduction of SOD [29] and CAT activity in asthmatic patients was stressed previously [30], which was in agreement with the changes observed in sensitized animals in this study. In addition, similar to the findings of the present study, upregulation of the release of Th2 cytokines (mainly IL-4, IL-5, and IL-13) and downregulation of the release of IFN- $\gamma$ were also noticed in asthmatic patients [30]. Therefore, the results of the present and previous studies [7] on antioxidant and anti-inflammatory properties of $A$. cepa suggest that the plant could be of therapeutic value in asthma, which should be confirmed in further studies.

\section{Conclusion}

A. cepa extract significantly lowered the levels of oxidant markers, IgE, and IL-4 but increased the levels of antioxidant markers, IFN- $\gamma$, and the IFN- $\gamma / \mathrm{IL}-4$ ratio in sensitized rats. Therefore, the plant extract could have potential in the treatment of asthma through antioxidant and immunomodulatory mechanisms.

\section{Acknowledgments}

This work was financially supported by a grant from the Research Council of the Mashhad University of Medical Sciences (Code: 910898), Mashhad, Iran.

\section{References}

1 Masoli M, Fabian D, Holt S, et al: The global burden of asthma: executive summary of the GINA Dissemination Committee report. Allergy 2004;59:469-478.

2 Bloemen K, Verstraelen S, Van Den Heuvel R, et al: The allergic cascade: review of the most important molecules in the asthmatic lung. Immunol Lett 2007;113:6-18.

3 Garcia G, Godot V, Humbert M: New chemokine targets for asthma therapy. Curr Allergy Asthma Rep 2005;5:155-160.

4 Nakagome K, Nagata M: Pathogenesis of airway inflammation in bronchial asthma. Auris Nasus Larynx 2011;38:555-563.

5 Roldan E, Sanchez-Moreno C, de Ancos B, et al: Characterisation of onion (Allium cepa L.) by-products as food ingredients with antioxidant and antibrowning properties. Food Chem 2008;108:907-916.

6 Lee BK, Jung Y-S: Allium cepa extract and quercetin protect neuronal cells from oxidative stress via PKC- $\varepsilon$ inactivation/ERK1/2 activation. Oxid Med Cell Longev 2016;2016: 2495624.

7 Graefe EU, Wittig J, Mueller S, et al: Pharmacokinetics and bioavailability of quercetin glycosides in humans. J Clin Pharmacol 2001; 41:492-499.

8 El-Aasr M, Fujiwara Y, Takeya M, et al: Onionin A from Allium cepa inhibits macrophage activation. J Nat Prod 2010;73:1306-1308.

9 Ueda H, Takeuchi A, Wako T: Activation of immune responses in mice by an oral administration of bunching onion (Allium fistulosum) mucus. Biosci Biotechnol Biochem 2013;77:1809-1813.

10 Oliveira TT, Campos KM, Cerqueira-Lima AT, et al: Potential therapeutic effect of Allium cepa $\mathrm{L}$. and quercetin in a murine model of Blomia tropicalis induced asthma. Daru 2015;23:18.

11 Javed MS, Khan MI, Randhawa MA, et al: Garlic (Allium sativum L.) as antimicrobial and antioxidant agents in beef sausages. Pak J Food Sci 2011;21:22-32.
12 Mellado-García P, Maisanaba S, Puerto M, et al: In vitro toxicological assessment of an organosulfur compound from Allium extract: cytotoxicity, mutagenicity and genotoxicity studies. Food Chem Toxicol 2017;99:231-240.

13 Mansour HA, Mahfouz H, Maher N: Antimutagenic potential of algal extracts on chromosomal aberrations in Allium cepa L. Acta Biol Hung 2017;68:137-149.

14 Shakeri F, Soukhtanloo M, Boskabady MH: The effect of hydro-ethanolic extract of Curcuma longa rhizome and curcumin on total and differential WBC and serum oxidant, antioxidant biomarkers in rat model of asthma. Iran J Basic Med Sci 2017;20:155-165.

15 Boskabady MH, Mehrjardi SS, Rezaee A, et al: The impact of Zataria multiflora Boiss extract on in vitro and in vivo Th1/Th2 cytokine (IFN- $\gamma /$ IL-4) balance. J Ethnopharmacol 2013;150:1024-1031.

16 Napimoga MH, Clemente-Napimoga JT, Macedo CG, et al: Quercetin inhibits inflammatory bone resorption in a mouse periodontitis model. J Nat Prod 2013;76:2316-2321.

17 Boskabady MH, Keyhanmanesh R, Khameneh $S$, et al: Potential immunomodulation effect of the extract of Nigella sativa on ovalbumin sensitized guinea pigs. J Zhejiang Univ Sci B 2011;12:201-209.

18 Byrami G, Boskabady MH, Jalali S, et al: The effect of the extract of Crocus sativus on tracheal responsiveness and plasma levels of IL-4, IFN-gamma, total NO and nitrite in ovalbumin sensitized guinea-pigs. J Ethnopharmacol 2013;147:530-535.

19 Sackesen C, Ercan H, Dizdar E, et al: A comprehensive evaluation of the enzymatic and nonenzymatic antioxidant systems in childhood asthma. J Allergy Clin Immunol 2008; 122:78-85.

20 Rahman I, Biswas SK, Kode A: Oxidant and antioxidant balance in the airways and airway diseases. Eur J Pharmacol 2006;533:222-239.
21 Ozaras R, Tahan V, Turkmen S, et al: Changes in malondialdehyde levels in bronchoalveolar fluid and serum by the treatment of asthma with inhaled steroid and $\beta_{2}$-agonist. Respirology 2000;5:289-292.

22 Albishi T, John JA, Al-Khalifa AS, et al: Antioxidative phenolic constituents of skins of onion varieties and their activities. J Funct Foods 2013;5:1191-1203.

23 Gawlik-Dziki U, Swieca M, Dziki D, et al: Quality and antioxidant properties of breads enriched with dry onion (Allium cepa L.) skin. Food Chem 2013;138:1621-1628.

24 Ahn NK, Kang BK, Kim KB, et al: Anti-inflammatory effect of ethanol extract from onion (Allium cepa L.) peel on lipopolysaccharide-induced inflammatory responses in RAW 264.7 cells and mice ears. J Korean Soc Food Sci Nutr 2015;44:1612-1620.

25 Park HJ, Lee CM, Jung ID, et al: Quercetin regulates Th1/Th2 balance in a murine model of asthma. Int Immunopharmacol 2009;9: 261-267.

26 Mlcek J, Jurikova T, Skrovankova S, et al: Quercetin and its anti-allergic immune response. Molecules 2016;21:623.

27 Kempuraj D, Madhappan B, Christodoulou S, et al: Flavonols inhibit proinflammatory mediator release, intracellular calcium ion levels and protein kinase $\mathrm{C}$ theta phosphorylation in human mast cells. Br J Pharmacol 2005;145: 934-944.

28 Sharma K, Assefa AD, Kim S, et al: Evaluation of total phenolics, flavonoids and antioxidant activity of 18 Korean onion cultivars: a comparative study. J Sci Food Agric 2014;94: 1521-1529.

29 Zinellu A, Fois AG, Sotgia S, et al: Plasma protein thiols: an early marker of oxidative stress in asthma and chronic obstructive pulmonary disease. Eur J Clin Invest 2016;46:181-188.

30 Yang LL, Huang MS, Huang CC, et al: The association between adult asthma and superoxide dismutase and catalase gene activity. Int Arch Allergy Immunol. 2011;156:373-380. 